\title{
Psicología
}

Artículo original

\section{Relationship between lifestyle and positive psychological functioning in university administrative staff}

\section{Relación entre el estilo de vida y el funcionamiento psicológico positivo en personal administrativo universitario}

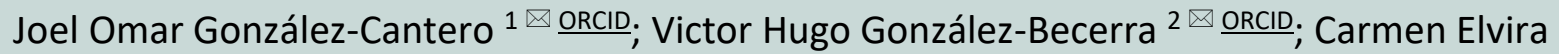
Hernández-Magaña $3 \bowtie \underline{\text { ORCID }}$; Fabiola Macías-Espinoza $4 \llbracket \underline{\text { ORCID }}$; José Ángel Morón-Vera 5 घ $\underline{\text { ORCID }}$; Alicia Abundis-Gutiérrez ${ }^{6 \square} \underline{\text { ORCID }}$

${ }^{1}$ PhD. in Psychology. Research Professor at the Center for Research in Behavior and Health, University of Guadalajara, Mexico.

2 PhD. in Behavioral Sciences. Research Professor at the Center for Research in Behavior and Health, University of Guadalajara.

${ }^{3}$ Master in Gerontology. Full-time Professor at the Center for Research in Behavior and Health, University of Guadalajara.

${ }^{4} \mathrm{PhD}$. in Occupational Health Sciences. Full-time Professor at the University Center for Health Sciences, University of Guadalajara.

${ }^{5}$ Master student in Health Psychology. Fellow of the Center for Research in Behavior and Health, University of Guadalajara.

${ }^{6}$ PhD. in experimental Psychology. Research Professor at the Center for Research in Behavior and Health, University of Guadalajara.

Fecha correspondencia:

Recibido: marzo 3 de 2020.

Aceptado: mayo 25 de 2021.

Forma de citar:

González-Cantero, J.O., González-

Becerra, V.H., Hernández-

Magaña, C.E., Macías-Espinoza,

F., Morón-Vera, J.A., \& Abundis-

Gutiérrez, A. (2021). Relationship

between lifestyle and positive

psychological functioning in

university administrative staff.

Rev. CES Psico, 14(3), 57-69.

https://dx.doi.org/10.21615/

cesp. 5473

Open access

(C) Derecho de autor

Licencia creative commons

Revisión por pares

Gestión por Open Journal System

\section{Abstract}

In Mexico, healthy lifestyle has a low prevalence. The importance of a healthy lifestyle lies in avoiding the emergence of a chronic non-communicable disease. Thus, university administrative personnel are a vulnerable population due to working conditions that prevent them from having a healthy lifestyle, so it is necessary to analyze psychological variables that can explain how to promote and develop a healthy lifestyle. The purposes of this study were to identify relationships among lifestyle (LS) and positive psychological functioning (PPF) and their differences by gender in the administrative staff; a cross-sectional and correlational study was conducted. University administrative staff ( $n=102)$, were recruited using the snowball sampling method, forming a non-probabilistic sample, completed the Fantastic Lifestyle Questionnaire and the Positive Psychological Functioning Scale. LS has a statistically significant correlation with PPF $(r=.355$, $\mathrm{p}=.001)$; in addition, it is worth pointing out that showing a low level of PPF implies a lower probability of having a healthy LS $(\Psi=$ $28.333,4.965$ - 161.675). Results suggest the relevance of 
DOI: $10.21615 /$ cesp. 5473

ISSNe: 2011-3080

Publica con nosotros interventions to develop psychological resources in people seeking the adoption of a healthy LS.

Keywords: lifestyle, positive psychological functioning, mental health, administrative personnel, university.

\section{Resumen}

En México, el estilo de vida saludable tiene una baja prevalencia. La importancia de un estilo de vida saludable radica en evitar la aparición de una enfermedad crónica no transmisible. Así, el personal administrativo universitario es una población vulnerable debido a las condiciones laborales que les impiden tener un estilo de vida saludable, por lo que es necesario analizar las variables psicológicas que pueden explicar cómo promoverlo y desarrollarlo. Los propósitos de este estudio fueron identificar las relaciones entre el estilo de vida (EV) y el funcionamiento psicológico positivo (FPP) y sus diferencias por sexo en personal administrativo universitario para lo cual se realizó un estudio transversal y correlacional. El personal administrativo universitario $(n=102)$ reclutado mediante el método de muestreo de bola de nieve, completó el Cuestionario de Estilo de Vida Fantástico y la Escala de Funcionamiento Psicológico Positivo. El EV presentó una correlación estadísticamente significativa con el FPP ( $r=.355, p=.001)$; además, vale la pena señalar que tener un bajo nivel de FPP implica una menor probabilidad de tener un EV saludable ( $\Psi=28.333,4.965$ - 161.675). Los resultados sugieren la relevancia de las intervenciones para desarrollar recursos psicológicos en personas que buscan la adopción de un EV saludable.

Palabras clave: estilo de vida, funcionamiento psicológico positivo, salud mental, personal administrativo, universidad.

\section{Introduction}

Lifestyle (LS), according to Lalonde (1996), is defined as the set of decisions that people make about their health over which they have a certain degree of control. The above definition gives an account of people's responsibility regarding their health; in this sense, LS according to Flórez (2007) is a set of habits that people adopt that may act as protective factors for health or risk factors of disease.

Thus, LS consists of a series of elements, such as eating habits, physical activity, relationships with others, the consumption of substances, precautionary behaviors, personality traits and 
work aspects among others, that are related to the state of people's health. When a LS is not healthy, it is a risk factor for developing a chronic disease (Cerecero, Hernández, Aguirre, Valdés, \& Huitrón, 2009).

In addition, it is important to highlight that LS is importantly related to psychological aspects, for example, World Health Organization (WHO) defines mental health as:

"Mental health is defined as a state of well-being in which every individual realizes his or her own potential, can cope with the normal stresses of life, can work productively and fruitfully, and is able to make a contribution to her or his community" (2018, parr.2).

Based on the above, the importance of psychological factors on LS can be noted. Psychologists have sought to identify what makes people adopt a healthy LS. Previously, the interest was focused on psychopathological aspects, but recently positive psychology has also looked at the positive qualities that individuals have, as well as the characteristics and environments of an optimal functioning that impel them towards a full life and well-being (Romero, Salas, Reinoza, García, \& Moreno, 2013; Rodríguez-Muñoz \& Sanz-Vergel, 2013).

Within positive psychology, positive psychological functioning (PPF) models have been proposed to explain the resources that give an individual favorable health outcome, allow for a better adaptation to the environment and change, and are stable and assimilable.

Recently, Merino and Privado (2015) consider that PPF evaluates 11 extensively studied psychological resources: self-esteem, resilience, curiosity, optimism, autonomy, vitality, environmental mastery, purpose in life, humor, enjoyment, and creativity. Self-esteem is defined as the global feeling of acceptance of oneself, of one's worth; resilience refers to the ability to overcome adversity and even grow with experience; curiosity is determined as the ability to be interested in knowing new things; optimism refers to the stable and widespread belief that positive things will happen; autonomy is the psychological domain of self- or perceived self-determination; vitality is understood as the feeling of being alive, alert and full of energy; environmental mastery is the ability to monitor, manage and effectively model the demands of daily life, and live in harmony with the purposes, needs and values of oneself; purpose in life involves striving for and attaining objectives that give meaning to life; humor includes seeing the comedic side of life and being able to laugh and make others laugh easily; enjoyment is defined as the ability to identify and make positive experiences possible daily; and 
creativity is the ability of an individual to find original and valuable solutions to problems, whether new or daily.

Organizations need to provide better working conditions for their workers (Ferrari, Basile, \& Prescilla, 2019) since university administrative personnel have frequent exposure to risk factors for the development of a chronic non communicable disease, due, mainly, to factors including shift work, work stress and work demands (Schröer, Haupt, \& Pieper, 2014).

For example, in a study with Mexican workers of a public health institution it was identified that even they have a high exposure to risk factors, so the authors concluded that it is necessary to train workers to improve their LS and thus improve their health profile (Velasco-Contreras, 2013). In the same sense, the study of Morales et al. (2018) in which lifestyle of university workers was evaluated indicates that the areas in which workers report dissatisfaction are health (in general) and vitality. In another study, also with university workers, Jiménez et al. (2017) identified that the level of lifestyle was medium.

Joseph-Shehu and Ncama (2020) pointed out that factors influencing health promoting lifestyle behaviour of university workers were lack of institutional health policy and protocol, work overload, lack of planned and consistent health promotion awareness, and economic factors. The above reflects the need to evaluate the lifestyle in the workplace, particularly when the workplace is the university because people who are part of a university, regularly function as social models, in this case, they could be models of a healthy LS and PPF.

Although there are no studies in which LS and PPF are related, a similar study identifies a relationship between a functional psychological capacity and a better health related to quality of life (González-Cantero et al., 2017; Uribe et al., 2010).

Based on the above, the objective of this work is to evaluate the relationship of LS and PPF, and their differences by gender in university administrative personnel. It is assumed as a hypothesis that LS and PPF will have a statistically significant relationship and that there will be no differences between men and women in both variables.

\section{Method}

A cross-sectional correlational design was used to examine if changes in LS are related to PPF. 


\section{Participants}

The sample was formed by 102 (80.31\%) of the 127 total university administrative personnel at CUValles of the Universidad de Guadalajara (México) recruited using the snowball sampling method, thus forming a non-probability sampling. Of the participants, 34 (33.3\%) were men and $68(66.7 \%)$ women. The age range was 23 to 62 years with a mean of 34.90 (SD $=8.38$ ). Regarding marital status, 47 (46.08\%) reported being single and $55(53.92 \%)$ married.

\section{Measures}

Fantastic Lifestyle Questionnaire. This instrument was originally designed by the Department of Family Medicine of McMaster University in Canada and was validated in the Mexican population obtaining a Cronbach alpha of .80 (Rodríguez, López, Munguía, Hernández, \& Martínez, 2003). This instrument is a Likert-type scale and consists of 25 items that in turn are distributed over nine domains of physical, psychological, and social components related to LS; these domains are: Family-friends, Activity, Nutrition, Tobacco/toxins, Alcohol, Sleep/seatbelts/stress, Personality type, Insight (anxiety, worry, depression), Career (workload). The questionnaire has five response options with a numerical value from 0 to 4 , where a higher score indicates a healthier LS. For this study, two categories (low level or unhealthy LS, and high level or healthy LS) were generated considering the mean plus a standard deviation, that is, the participants who scored ${ }^{3} 88.25$ on the total scale were assigned to the high level, while those who obtained $f 88.24$ were located on the low level (Abraira, 2002).

Positive Psychological Functioning Scale. This scale was validated in the Mexican population and a Cronbach alpha of .91 was reported (Merino, Privado, \& García, 2015). It is a Likert-type scale consisting of 33 items grouped in 11 dimensions: Self-esteem, Resilience, Optimism, Creativity, Autonomy, Environmental Mastery, Vitality, Purpose in Life, Humor, Enjoyment and Curiosity. It has five response options, from "1" (completely disagree) to "5" (completely agree), where a higher score indicates a better PPF. For this study, the two categories (low and high level of PPF) were generated considering the mean plus a standard deviation (Abraira, 2002), that is, the participants who scored ${ }^{3} 159.7$ on the scale total were assigned to the high level, while those who obtained $f 159.6$ were located on the low level.

\section{Procedure}

Initially, this study was submitted for evaluation to the Departmental College of CUValles of the Universidad de Guadalajara, and once it was evaluated, the approval and its registration in the Research Coordination were obtained. For the application of the instrument, three psychology 
students were trained. The application was made during the working day. The students explained to the workers that the approximate duration of the application of the instrument was 30 minutes. The workers were told that their participation was voluntary and anonymous and that once they started participating, they could decline if they wished. It was mentioned that those who agreed to participate needed to sign the informed consent, where the details of the research, the rights of the participants and the contact details of the researcher in charge were explained. The data were collected within a period of two months (June - July 2018). The participants did not receive any financial or academic compensation for their participation in the study. No participant refused to answer the questionnaire.

\section{Statistical analyses}

Initially, the correlations were made based on Pearson's $r$, and the odds ratio was used to evaluate the probability that the PPF increases a healthier LS. Descriptive analyses (mean and standard deviation) of the LS scores and the PPF (from the total score and from the factors of both scales) were performed. Then, based on Student's $t$ test, the results obtained by gender of both variables were compared.

\section{Ethical considerations}

This study is categorized as minimal risk. In addition, it complied with all ethical standards of work with human beings, in accordance with the Declaration of Helsinki, and with the provisions set forth in the Ley General de Salud de los Estados Unidos Mexicanos in its Fifth Title "Research for Health" Single Chapter Article 100, as well as with those of the Código Ético del Psicólogo issued by the Sociedad Mexicana de Psicología.

\section{Results}

No correlation between LS and PPF with age, sex or marital status was identified. With respect to the correlational analysis, LS has a statistically significant positive correlation with PPF ( $r=$ $.355, p=.001)$; in addition, it is worth noting also that LS has significant positive correlations with all PPF factors except for Resilience. PPF factors, Environmental Mastery and Vitality $(r=$ $.464, p=.001$ and $r=.488, p=.001$ respectively) stand out as statistically significant, moderate and positive correlations with LS. This implies that feeling alive, alert and full of energy (Vitality) and have the ability to monitor, manage and effectively model the demands of daily life, and live in harmony with the purposes, needs and values of oneself (Environmental mastery) is correlated with LS in general but, particularly, with factor as Activity, Sleep/seatbelts/stress, Personality type, Insight and Career. The other correlations are shown in Table 1. 
Table 1. Correlations between lifestyle and positive psychological functioning.

\begin{tabular}{|c|c|c|c|c|c|c|c|c|c|c|c|c|}
\hline & $\begin{array}{l}\text { Self- } \\
\text { esteem }\end{array}$ & Resilience & Optimism & Creativity & Autonomy & $\begin{array}{l}\text { Environmental } \\
\text { mastery }\end{array}$ & Vitality & $\begin{array}{l}\text { Purpose in } \\
\quad \text { life }\end{array}$ & Humor & Enjoyment & Curiosity & $\begin{array}{c}\text { Positive Psychological } \\
\text { Functioning }\end{array}$ \\
\hline \multirow{2}{*}{ Lifestyle } & $.296^{* *}$ & .130 & $.252^{*}$ & $.279 * *$ & $.217^{*}$ & $.464^{* *}$ & $.488^{* *}$ & $.242^{*}$ & $.277^{* *}$ & $.249^{*}$ & $.266^{* *}$ & $.355^{* *}$ \\
\hline & .003 & .192 & .010 & .004 & .029 & .001 & .001 & .014 & .005 & .011 & .007 & .001 \\
\hline \multirow{2}{*}{ Family-friends } & .170 & .042 & .133 & .067 & .100 & .065 & .144 & .125 & .192 & .061 & .084 & .133 \\
\hline & .088 & .678 & .184 & .506 & .317 & .516 & .148 & .211 & .053 & .541 & .401 & .181 \\
\hline \multirow{2}{*}{ Activity } & .178 & -.001 & .151 & $.220^{*}$ & .172 & $.281^{* *}$ & $.314^{* *}$ & $.224^{*}$ & $.254^{* *}$ & .175 & $.216^{*}$ & $.245^{*}$ \\
\hline & .074 & .993 & .130 & .026 & .083 & .004 & .001 & .024 & .010 & .078 & .029 & .013 \\
\hline \multirow{2}{*}{ Nutrition } & .028 & .070 & .018 & .148 & .025 & .110 & .160 & .085 & .063 & .096 & .060 & .096 \\
\hline & .777 & .487 & .855 & .137 & .806 & .271 & .108 & .397 & .528 & .337 & .550 & .338 \\
\hline \multirow{2}{*}{$\begin{array}{l}\text { Tobacco/ } \\
\text { toxins }\end{array}$} & -.025 & .015 & -.056 & -.027 & -.051 & .015 & .010 & .042 & .044 & -.066 & .036 & -.006 \\
\hline & .802 & .883 & .574 & .787 & .608 & .880 & .924 & .677 & .662 & .507 & .717 & .949 \\
\hline \multirow{2}{*}{ Alcohol } & .132 & -.032 & .015 & .004 & .063 & .078 & .070 & .094 & -.056 & .028 & .185 & .067 \\
\hline & .185 & .748 & .882 & .968 & .527 & .435 & .482 & .346 & .574 & .780 & .063 & .501 \\
\hline \multirow{2}{*}{$\begin{array}{l}\text { Sleep/seatbelts } \\
\text { /stress }\end{array}$} & .143 & .056 & .097 & .154 & .059 & $.354^{* *}$ & $.349^{* *}$ & -.004 & 109 & .092 & .048 & .164 \\
\hline & .151 & .575 & .331 & .121 & .554 & .000 & .000 & .968 & .274 & .358 & .634 & .099 \\
\hline \multirow{2}{*}{$\begin{array}{l}\text { Personality } \\
\text { type }\end{array}$} & $.323^{* *}$ & $.276^{* *}$ & $.322^{* *}$ & $.268 * *$ & $.245^{*}$ & $.503^{* *}$ & $.536^{* *}$ & $.263^{* *}$ & $.236^{*}$ & $.389^{* *}$ & $.346^{* *}$ & $.415^{* *}$ \\
\hline & .001 & .005 & .001 & .006 & .013 & .001 & .001 & .008 & .017 & .001 & .001 & .001 \\
\hline \multirow{2}{*}{ Insight } & $.270^{* *}$ & .125 & $.346^{* *}$ & $.297^{* *}$ & $.317^{* *}$ & $.492^{* *}$ & $.393^{* *}$ & $.245^{*}$ & $.218^{*}$ & $.205^{*}$ & $.203^{*}$ & $.348^{* *}$ \\
\hline & .006 & .211 & .001 & .002 & .001 & .001 & .001 & .013 & .027 & .039 & .040 & .001 \\
\hline \multirow{2}{*}{ Career } & $.220^{*}$ & .006 & .126 & .121 & .091 & $.215^{*}$ & $.262^{* *}$ & .080 & .174 & .148 & .123 & .177 \\
\hline & .026 & .955 & .206 & .225 & .364 & .030 & .008 & .425 & .080 & .138 & .218 & .076 \\
\hline
\end{tabular}

$*=p<.05, * *=p<.01$ (bilateral) 
A simple linear regression was calculated to predict LS based on PPF. A significant regression equation was found $(\mathrm{F}[1,100]=14.400, p<.001)$, with an $R^{2}$ of .126. Participants' predicted LS is equal to $54.704+.175$ (PPF) when is measured in points. Participants' average LS increased .175 for each point of PPF.

Based on the results of the correlations, also, the odds ratio was used to estimate the likelihood that a low PPF implies for having a low-level (unhealthy) LS; in this regard it is observed that having a low PPF implies a higher probability of having an unhealthy LS compared to the probability of having an unhealthy LS when the PFF has a high level $(\Psi=28.333,4.965-$ 161.675) as can be seen in table 2 .

Table 2. Odds ratio by positive psychological functioning level.

$\begin{array}{llll} & \text { Low } L S & \text { High } L S & \boldsymbol{\Psi} \\ \text { Low PPF } & 85(97.7) & 9(60.0) & 28.333 \\ \text { High PPF } & 2(2.3) & 6(40.0) & (4.965-161.675)\end{array}$

Regarding the differences in LS by gender, a statistically significant difference was identified only in the Insight factor, which is related to anxiety, worry and depression, where women obtained a lower average than men (see Table 3). This implies that both men and women have similar levels in LS factors, so it can be pointed out that sex, in this sample, is not a variable related to $\mathrm{LS}$.

Table 3. Descriptive measures of lifestyle and their comparison by sex.

\begin{tabular}{lccccc} 
& Men & Women & Total & Student's $\boldsymbol{p}$ & $\boldsymbol{p}$ \\
\hline Lifestyle & $80.15(8.81)$ & $79.13(8.82)$ & $79.47(8.78)$ & 0.548 & .585 \\
\hline Family-friends & $10.12(1.73)$ & $9.93(1.73)$ & $9.99(1.73)$ & 0.524 & .602 \\
\hline Activity & $4.76(1.89)$ & $4.21(1.83)$ & $4.39(1.86)$ & 1.436 & .154 \\
\hline Nutrition & $10.82(2.34)$ & $11.18(2.19)$ & $11.06(2.23)$ & -0.749 & .455 \\
\hline Tobacco/toxins & $9.88(2.34)$ & $10.49(1.45)$ & $10.28(1.81)$ & -1.373 & .176 \\
\hline Alcohol & $7.41(0.98)$ & $7.76(0.62)$ & $7.65(0.77)$ & -1.900 & .064 \\
\hline Sleep/seatbelts/stress & $7.88(1.98)$ & $7.51(1.87)$ & $7.64(1.90)$ & 0.917 & .361 \\
\hline Personalitytype & $8.79(2.21)$ & $8.85(2.03)$ & $8.83(2.08)$ & -0.134 & .894 \\
\hline Insight & $9.76(1.72)$ & $8.99(1.90)$ & $9.25(1.87)$ & 2.009 & $.047 *$ \\
\hline Career & $7.18(1.08)$ & $6.94(1.22)$ & $7.02(1.17)$ & 0.951 & .344
\end{tabular}

$*=p<.05$. 
In other hand, comparing PPF by gender, no statistically significant differences were identified either in the scale in general or in its factors (see Table 4). This implies that both men and women have similar levels in the PPF factors, so it can be pointed out that sex, in this sample, is not a variable related to PPF.

Table 4. Descriptive measures of positive psychological functioning and their comparison by sex.

\begin{tabular}{|c|c|c|c|c|c|}
\hline & Men & Women & Total & Student's $t$ & $p$ \\
\hline Positive Psychological & $144.18(14.98)$ & 140.69 (19.13) & $141.85(17.85)$ & 0.929 & .355 \\
\hline Self-esteem & $13.59(2.00)$ & $13.13(2.33)$ & $13.28(2.23)$ & .973 & .333 \\
\hline Resilience & $13.35(1.75)$ & $13.32(2.08)$ & $13.33(1.97)$ & 0.071 & .944 \\
\hline Optimism & $13.35(1.70)$ & $13.29(2.08)$ & $13.31(1.95)$ & 0.143 & .887 \\
\hline Creativity & $13.06(1.65)$ & $12.41(1.92)$ & $12.63(1.85)$ & 1.675 & .097 \\
\hline Autonomy & $13.62(1.34)$ & $13.04(2.10)$ & $13.24(1.89)$ & 1.445 & .151 \\
\hline Enviromental mastery & $11.24(2.00)$ & 10.65 (1.99) & $10.84(2.00)$ & 1.401 & .164 \\
\hline Vitality & $12.76(1.97)$ & $12.51(2.14)$ & $12.60(2.07)$ & .569 & .570 \\
\hline Purpose in life & $13.62(1.61)$ & $13.24(2.20)$ & $13.36(2.08)$ & 0.897 & .372 \\
\hline Humor & $13.50(1.78)$ & $12.97(2.04)$ & $13.15(1.96)$ & 1.286 & .202 \\
\hline Enjoyment & $12.97(1.76)$ & $13.10(1.93)$ & $13.06(1.87)$ & -0.335 & .738 \\
\hline Curiosity & $13.12(1.71)$ & $13.01(2.20)$ & $13.05(2.04)$ & 0.238 & .812 \\
\hline
\end{tabular}

\section{Discussion}

Based on the results, a statistically significant correlation can be noted, albeit with a low coefficient, between LS and PPF, which is also evidenced by simple linear regression; in addition, the correlation of LS with the PPF factors Environmental Mastery and Vitality is moderate, which imply, in general, having the skills needed to face the demands of daily life and to strive to achieve the objectives that give meaning to life, respectively. This suggests the need to analyze and propose interventions that address the behavioral approach, but also the cognitive aspects related to $L S$.

It should be noted that the probability of a low PPF contributing to an unhealthy LS is an important consideration essentially because being informed about how to develop a healthy LS is not enough to achieve it. 
There are no studies relating LS and PPF, but there are similar ones. For example, the study conducted by Bränström (2013), in which a moderating role of positive states of mind on the association between perceived stress and psychological outcomes was confirmed. This suggests that people who experience a higher frequency of positive states of mind perceive a lower state of depression and anxiety, and better health. In another similar study by Jiménez et al. (2017), a positive and significant relationship was found between assertiveness and LS.

This study identifies a low LS in university administrative personnel, so an intervention to improve LS might be necessary as Camacho, Echeverría and Reynoso (2010) recommend based on the results of a study with university workers, in which 67 of the 86 participants were identified as presenting some risk for suffering from a chronic non-communicable disease, either because of their hereditary background or their LS.

In a study by Joseph-Shehu et al. (2019) age, sex and marital status were factors that statistically influenced LS while in this study, the same factors did not correlate with LS. Also, in the same study by Joseph-Shehu et al. LS has a medium level while in this study $87 \%$ of the sample had a low level of LS.

Concerning PPF, there is evidence that it contributes to achieving optimum physical health (Kubzansky, Boehm, \& Segerstrom, 2015), partly because it generates biological processes that benefit health, but also because according to the results it is a variable that relate to LS.

For example, the study by Casellas-Grau, Vives, Font and Ochoa (2016), which reviews studies related to PPF in patients with breast cancer, points out the need for health professionals to consider the psychosocial aspects of patients to promote positive functioning.

As to the differences by gender, regarding LS, only the Insight factor had a statistically significant difference, where men scored higher than women. This contrasts with the results found in Sharratt, Sharratt, Smith, Howell and Davenport (1984), where women scored higher than men in this domain, as well as in Tobacco and Career. Also, Simpson, Albert, Wilson, Ciliska and Evans (1984) identified a statistically significant difference between genders in LS, where women scored higher than men, nevertheless, they suggest that the differences were too small to have practical relevance. On other hand, Castiblanco, López, López, Menjura and Forero (2016) found no differences in gender in the global LS scale in health-care workers. 
Concerning PPF, there were no statistically significant differences found in gender, and other studies that have included this variable, have not reported any differences in their results.

To conclude, these results show the feasibility of assessing lifestyle, particularly in university administrative personnel to then propose interventions to help them develop a healthier lifestyle. It is necessary, in order to achieve a healthy university, to address the needs not only of the students and teachers, but also of university administrative personnel.

\section{Limitations}

The use of self-reporting measures may prove a limitation, since the phenomenon of social desirability often causes people to report an ideal or what is expected from their behavior in a certain aspect, so it is possible that with another type of evaluation, the data obtained in the averages of LS and PPF would be different.

Another limitation of this study is that due to its correlational design it is not possible to establish whether the FPP is a predictor of LS or vice versa, so it is recommended that future studies consider other designs that clarify if there is a causality of a factor on the other.

Furthermore, more studies are necessary to evaluate this relationship, specifically studies using a random sampling since it was not possible in this study due to financial issues.

\section{Conflicts of Interest}

The authors of this article declare no conflict of interest.

\section{Referencias}

Abraira, V. (2002). Desviación estándar y error estándar. SEMERGEN - Medicina de Familia, 28(11), 621-623. https://doi.org/10.1016/S1138-3593(02)74138-5

Bränström, R. (2013). Frequency of positive states of mind as a moderator of the effects of stress on psychological functioning and perceived health. BMC Psychology, 1(1), 1-7. https://doi.org/10.1186/2050-7283-1-13

Camacho, L. A., Echeverría, S. B., \& Reynoso, L. (2010). Estilos de vida y riesgos en la salud de trabajadores universitarios. Journal of Behavior, Health \& Social Issues, 2(1), 91-103. https://doi.org/10.22201/fesi.20070780.2010.2.1.20421

Casellas-Grau, A., Vives, J., Font, A., \& Ochoa, C. (2016). Positive psychological functioning in breast cancer: An integrative review. The Breast, 27, 136-168. https://doi.org/ $\underline{10.1016 / \text { i.breast.2016.04.001 }}$ 
Castiblanco, D. S., López, P., López, S. J., Menjura, H., \& Forero, V.H. (2016). Estilos de vida en trabajadores de salud. Paper presented at the II Congreso Internacional de Investigación en Ciencias de la Salud, Educación y Música (XI Jornada Corpista de Investigación), Cajicá, Colombia.

Cerecero, P., Hernández, B., Aguirre, D., Valdés, R., \& Huitrón, G. (2009). Estilos de vida asociados al riesgo cardiovascular global en trabajadores universitarios del Estado de México. Salud Pública de México, 51(6), 465-473. https://doi.org/10.1590/s0036$\underline{36342009000600004}$

Ferrari, H., Basile, J., \& Prescilla, J. (2019). Clima e suporte organizacional: avaliação e relação entre as temáticas. Revista CES Psicología, 12(2), 65-82. http://dx.doi.org/10.21615/cesp.12.2.6

Flórez, L. (2007). Psicología social de la salud: promoción y prevención. El Manual Moderno.

González-Cantero, J. O., Oropeza-Tena, R., Padrós-Blázquez, F., Colunga-Rodríguez, C., MontesDelgado, R., \& González-Becerra, V. H. (2017). Capital psicológico y su relación con el estilo de vida de universitarios mexicanos. Nutrición Hospitalaria, 34(2), 439-443. https://dx.doi.org/10.20960/nh.172

Jiménez, E., Álvarez, A., Reyes, B. L., Casique, L., Herrera, J. M., \& Sánchez, M. (2017). Healthpromoting lifestyle and assertiveness in university workers. Investigación y Educación en Enfermería, 35(1), 26-34. https://doi.org/10.17533/udea.iee.v35n1a04

Joseph-Shehu, E., \& Ncama, B. (2019). Factors Influencing University Staff Health-Promoting Lifestyle Behaviours in Nigeria: A Qualitative Descriptive Study. Global Journal of Health Science, 12(1), 46-59. https://doi.org/10.5539/gjhs.v12n1p46

Joseph-Shehu, E., Ncama, B. P., Irinoye, O., \& Sibanda, W. (2019). Assessment of Healthpromoting lifestyle behaviour (HPLB) of University workers in Nigeria. Research Journal of Health Sciences, 7(4), 322-333. http://dx.doi.org/10.4314/rejhs.v7i4.7

Kubzansky, L. D., Boehm, J. K., \& Segerstrom, S. C. (2015). Positive Psychological Functioning and the Biology of Health. Social and Personality Psychology Compass, 9(12), 645-660. https://doi.org/10.1111/spc3.12224

Lalonde, M. (1996). El concepto de "campo de la salud": Una perspectiva canadiense. En OPS (Ed.). Promoción de la salud: Una antología. Washington, D. C.: Organización Panamericana de la Salud, Publicación Científica No. 557, pp. 3-5. https://iris.paho.org/bitstream/handle/10665.2/3318/Promocion\%20de\%20la\%20salu d\%20una\%20antologia.pdf?sequence $=1 \&$ isAllowed $=y$

Merino, M. D., \& Privado, J. (2015). Positive Psychological Functioning. Evidence for a new construct and its measurement. Anales de Psicología, 31(1), 45-54. https://doi.org/10.6018/analesps.31.1.171081 
Merino, M. D., Privado, J., \& Gracia, Z. (2015). Validación mexicana de la Escala de Funcionamiento Psicológico Positivo. Perspectivas en torno al estudio del bienestar y su medida. Salud Mental, 38(2),109-115. https://doi.org/10.17711/sm.01853325.2015 .015

Morales, I., Henriquez, S., Fuentes, P., Muñoz, P., Jara, P., Parada, D., \& Robledo, P. (2018). Estilo de vida en trabajadores de la Universidad Adventista de Chile. Revista Horizonte Ciencias de la Actividad Física, 9(1), 39-40. http://revistahorizonte.ulagos.cl/index.php/horizonte/article/view/128

Rodríguez, R., López, J. M., Munguía, C., Hernández, J. L., \& Martínez, M. (2003). Validez y consistencia del instrumento FANTASTIC para medir estilo de vida en diabéticos. Revista Médica del Instituto Mexicano del Seguro Social, 41(3), 211-220. https://doi.org/10.21840/siic/150140

Rodríguez-Muñoz, A., \& Sanz-Vergel, A. I. (2013). Happiness and well-being at work: A special issue introduction. Journal of Work and Organizational Psychology 29(3), 95-97. http://dx.doi.org/10.5093/tr2013a14

Romero, K. A, Salas, M. L., Reinoza, M., García, M., \& Moreno, R. (2013). Psicología positiva: un estilo de vida llevado a la educación. Educere, 17(58), 443-453.

Schröer, S., Haupt, J., \& Pieper, C. (2014). Evidence-based lifestyle interventions in the workplace-an overview. Occupational Medicine, 64(1), 8-12. https://doi:10.1093/occmed/kqt136

Sharratt, K., Sharratt, M. T., Smith, D. M., Howell, M. J., \& Davenport, L. (1984). FANTASTIC Lifestyle Survey of University of Waterloo Employees. Canadian Family Physician, 30, 1869-1872.

Simpson, R., Albert, W., Wilson, D. M. C., Ciliska, D., \& Evans C. E. (1984). Lifestyle Assessment: Part 4. The Halton Health Promotion Survey. Canadian Family Physician, 30, 2147-2155.

Uribe, Y. L., Dosman, V. A., Triviño, L. P., Agredo, R. A., Jerez, A. M., \& Ramírez-Vélez, R. (2010). Capacidad funcional y calidad de vida relacionada con la salud en trabajadores de una institución universitaria. Revista Ciencias de la Salud, 8(2), 33-43. https://doi.org/10.35537/10915/5429

Velasco-Contreras, M. E. (2013). Perfil de salud de los trabajadores del Instituto Mexicano de Seguro Social. Revista Médica del Instituto Mexicano del Seguro Social, 51(1), 12-25. https://doi.org/10.21840/siic/150140

World Health Organization [WHO]. (2018). Mental health: strengthening our response. https://www.who.int/news-room/fact-sheets/detail/mental-health-strengthening-ourresponse 